\title{
Multimodal immunogenic cancer cell death as a consequence of anticancer cytotoxic treatments
}

\author{
$H$ Inoue $^{1,2,3}$ and $K \operatorname{Tani}^{*, 1,3}$
}

Apoptotic cell death generally characterized by a morphologically homogenous entity has been considered to be essentially non-immunogenic. However, apoptotic cancer cell death, also known as type 1 programmed cell death (PCD), was recently found to be immunogenic after treatment with several chemotherapeutic agents and oncolytic viruses through the emission of various danger-associated molecular patterns (DAMPs). Extensive studies have revealed that two different types of immunogenic cell death (ICD) inducers, recently classified by their distinct actions in endoplasmic reticulum (ER) stress, can reinitiate immune responses suppressed by the tumor microenvironment. Indeed, recent clinical studies have shown that several immunotherapeutic modalities including therapeutic cancer vaccines and oncolytic viruses, but not conventional chemotherapies, culminate in beneficial outcomes, probably because of their different mechanisms of ICD induction. Furthermore, interests in PCD of cancer cells have shifted from its classical form to novel forms involving autophagic cell death (ACD), programmed necrotic cell death (necroptosis), and pyroptosis, some of which entail immunogenicity after anticancer treatments. In this review, we provide a brief outline of the well-characterized DAMPs such as calreticulin (CRT) exposure, high-mobility group protein B1 (HMGB1), and adenosine triphosphate (ATP) release, which are induced by the morphologically distinct types of cell death. In the latter part, our review focuses on how emerging oncolytic viruses induce different forms of cell death and the combinations of oncolytic virotherapies with further immunomodulation by cyclophosphamide and other immunotherapeutic modalities foster dendritic cell (DC)-mediated induction of antitumor immunity. Accordingly, it is increasingly important to fully understand how and which ICD inducers cause multimodal ICD, which should aid the design of reasonably multifaceted anticancer modalities to maximize ICD-triggered antitumor immunity and eliminate residual or metastasized tumors while sparing autoimmune diseases.

Cell Death and Differentiation (2014) 21, 39-49; doi:10.1038/cdd.2013.84; published online 5 July 2013

Facts

- Accelerated progresses and discoveries in the field of oncology, immunology, and virology have made it possible to translate several emerging immunostimulatory strategies to treat malignant cancers towards promising clinical benefits.

- Profound understanding of the process of immunogenic cell death (ICD) induction by different ICD inducers such as certain chemotherapeutic agents and oncolytic viruses has highlighted the importance of immunological antitumor effects and proposed novel anticancer therapies.

- The execution of different types of programmed cell death (PCD), including apoptosis, autophagy, necroptosis, and pyroptosis, which are driven by a plethora of stimuli, was recently found to be regulated by orchestrated interactions among them, and importantly, some of these types of PCD exhibit an ICD property.

- Tumors and cancer cells treated with certain chemotherapeutic agents and oncolytic viruses can undergo ICD and release tumor-associated antigens (TAAs) accompanied by diverse danger-associated molecular patterns (DAMPs) and inflammatory cytokines to restore the tumor microenvironment and incite TAA-specific antitumor immunity.

\section{Open Questions}

- What are the recent advances in the development of anticancer immunotherapeutic modalities in clinical settings?

\footnotetext{
${ }^{1}$ Division of Molecular and Clinical Genetics, Medical Institute of Bioregulation, Kyushu University, Fukuoka, Japan; ${ }^{2}$ Research Institute for Diseases of the Chest, Graduate School of Medical Sciences, Kyushu University, Fukuoka, Japan and ${ }^{3}$ Department of Advanced Molecular and Cell Therapy, Kyushu University Hospital,Kyushu University, Fukuoka, Japan

*Corresponding author: K Tani, Division of Molecular and Clinical Genetics, Medical Institute of Bioregulation, Kyushu University, 3-1-1 Maidashi, Higashi-ku, Fukuoka 812-8582, Japan. Tel: + 8192642 6449; Fax: + 8192642 6444; E-mail: taniken@ bioreg.kyushu-u.ac.jp

Keywords: ICD; DAMPs; apoptosis; necroptosis; immunotherapeutic anticancer agents; oncolytic virotherapy

Abbreviations: ICD, immunogenic cell death; PCD, programmed cell death; PAMPs, pathogen-associated molecular patterns; DAMPs, danger-associated molecular patterns; ecto-CRT, calreticulin exposure; HMGB1, high-mobility group protein B1; ATP, adenosine triphosphate; PS, phosphatidylserine; Hsp, heat-shock protein; ACD, autophagic cell death; ER, endoplasmic reticulum; ROS, reactive oxygen species; APCs, antigen-presenting cells; DCs, dendritic cells; TAAs, tumor-associated antigens; GM-CSF, granulocyte-macrophage colony-stimulating factor; PDT, photodynamic therapy; CVB3, coxsackievirus B3; CSCs, cancer stem cells Received 11.3.13; revised 06.5.13; accepted 14.5.13; Edited by M Piacentini; published online 05.7.13
} 
- In response to diversified ICD inducers, how are DAMPs such as CRT, high-mobility group protein B1 (HMGB1), and ATP expressed by or released from the dying cancer cells?

- How do the diverse types of PCD differentially induce ICD to mount an efficient antitumor immunity?

- What are the prerequisites for an ideal ICD inducer to obtain an optimum level of ICD for long-lasting antitumor effects?

- It is vital to understand the molecular mechanisms of how ICD inducers, for example, infection with oncolytic viruses and resultant DAMPs, affect the host immune system. Can manipulation of ICD induction and/or combined strategies synergize with current or emerging oncolytic virotherapies?

The concept of immunogenic cell death (ICD) has recently been introduced to describe dying cancer cells that release endogenous danger molecules, the so-called damageassociated molecular patterns (DAMPs), after the exposure to certain cytotoxic agents to be recognized by antigenpresenting cells (APCs) such as dendritic cells (DCs) followed by formation of T-cell-mediated adaptive immunity. ${ }^{1}$ Although it has long been considered that apoptotic cell death is tolerogenic, DAMPs have also been found to be released from cells undergoing apoptosis, providing a promising anticancer efficacy. ${ }^{2-4}$ Therefore, comprehension of ICD induction gradually increases its significance, particularly in the field of cancer immunotherapy.

Overall prognosis of advanced cancer patients still remains dismal, thus making it imminent for oncologists to develop novel anticancer strategies. Recently, sipuleucel-T (Provenge, Dendreon, Seattle, WA, USA), indicated for patients with metastatic castration-resistant prostate cancer, received FDA's approval as the first therapeutic cancer vaccine. ${ }^{5}$ In addition, extensive Phase II clinical trials have demonstrated that the oncolytic herpes simplex virus talimogene laherparepvec (T-Vec, Amgen Inc., Thousand Oaks, CA, USA) ${ }^{6}$ and vaccinia virus JX-547 (Pexa-Vec, Jennerex Biotherapeutics, Inc., San Francisco, CA, USA), ${ }^{7}$ both of which carry the gene encoding the immunostimulatory cytokine granulocyte-macrophage colony-stimulating factor (GM-CSF), hold great promise for the treatment of advanced cancer patients. Furthermore, cytotoxic T-cell responses directed against oncolytic virus-infected cancer cells have been identified as an essential factor in the process of destruction of cancer. ${ }^{8}$ Moreover, proinflammatory cytokines generated in the virus-infected cancer cells can restore the immunosuppressive tumor microenvironment. ${ }^{9-11}$ Thus, oncolytic viruses are recently viewed as anticancer immunotherapeutic agents. These backgrounds make it imperative to update the molecular pathways and/or cellular constituents that regulate ICD.

Here, we review the progress of research on ICD, emphasizing how apoptotic, autophagic, and necroptotic cell death, called type 1, 2, and 3 PCD, respectively, are induced by various ICD inducers to achieve successful antitumor immunity. These multiple modes can be categorized by describing initiating events, intermediated changes, terminal cellular events, and their immunological responses, which are summarized in Table 1 . In the later section, we outline the characteristics of anticancer agents and oncolytic viruses and how they induce diversified forms of cell death and interact with host's immune system.

\section{Apoptotic Cell Death as ICD}

From ten million to billions of cells die per day as a consequence of normal tissue turnover, ${ }^{12}$ which are vital for organisms to retain homeostasis. ${ }^{13,14}$ Therefore, the existence of multiple modes of cell death in nature is not surprising. Apoptosis, type 1 PCD, is a specialized form of cell death, characterized by typical morphological changes, including chromatin condensation, nuclear fragmentation, and membrane blebbing (Table 1). ${ }^{15}$ Apoptosis occurs ubiquitously in normal tissues and causes 'quiet' cell death that uses phosphatidylserine (PS) as an 'eat-me' signal to be quickly recognized by peripheral APCs. Although apoptotic cell death has been historically considered to be nonimmunogenic, ${ }^{16}$ recent studies unraveled that several antineoplastic agents, including doxorubicin, ${ }^{1,17}$ oxaliplatin, ${ }^{18,19}$ cisplatin, ${ }^{20}$ and irradiation, ${ }^{21,22,23}$ can trigger immunogenic apoptosis. ${ }^{2}$ Mechanistically, the immunogenic apoptotic bodies induced by exposure to doxorubicin are sensed by APCs through their TLR-2/TLR-9-MyD88 signaling pathways. ${ }^{17}$

\section{DAMPs: as Effectors in ICD}

The primary conceptual theory of the pattern recognition of pathogen-associated molecular patterns (PAMPs), such as viral or bacterial components, has failed to fully explain the consequence of immunogenicity. Thus, the secondary concept of DAMPs has been proposed, which could provoke an immune response. ${ }^{24}$ Released DAMPs as hallmarks of ICD consisted of adenosine triphosphate (ATP), high-mobility group protein B1 (HMBG1), and exposed molecules on the outer membrane of dying cells such as CRT (ecto-CRT), heat-shock proteins (Hsp90 and Hsp70), and endoplasmic reticulum (ER) sessile proteins. ${ }^{25,26,27}$ The excretion of DAMPs was considered to occur during necrosis under inflammatory and/or pathological conditions. However, DAMPs have recently been reported to be produced from apoptotic cancer cells treated with chemotherapy ${ }^{1,18}$ or radiotherapy. ${ }^{21}$

\section{ICD Inducers}

ICD inducers include multiple anticancer therapeutic modalities. It has been recently proposed that they can be classified into two categories, type I or II ICD inducers, based on their distinct actions to induce ER stress leading to apoptotic cell death (Tables 2 and 3). ${ }^{27,28}$ The majority of ICD inducers such as chemotherapeutic agents (mitoxantrone, ${ }^{29}$ anthracyclines, ${ }^{2,30,31}$ oxaliplatin, ${ }^{18,19}$ and cyclophosphamide ${ }^{32}$ ), shikonin, ${ }^{33,34}$ the proteasome inhibitor bortezomib, $^{35}$ and $7 \mathrm{~A} 7$ (an epidermal growth factor receptor-specific antibody), ${ }^{36}$ cardiac glycosides, ${ }^{37}$ and the histone deacetylase inhibitor (vorinostat) ${ }^{38}$ are categorized as type I ICD inducers that primarily target cytosolic proteins, plasma membranes, or nucleic proteins. They also induce ER stress via collateral effects. Bortezomib, cardiac glycosides, 
Table 1 Comparison of multiple forms of programmed cell death and necrosis

\begin{tabular}{|c|c|c|c|c|c|}
\hline & $\begin{array}{l}\text { Apoptosis (type } 1 \\
\text { PCD) }\end{array}$ & $\begin{array}{l}\text { Autophagic cell } \\
\text { death (type } 2 \text { PCD) }\end{array}$ & Necroptosis (type 3 PCD) & Pyroptosis & Necrosis \\
\hline $\begin{array}{l}\text { Mode of cell } \\
\text { death }\end{array}$ & Programmed & Programmed & Programmed & Programmed & Accidental \\
\hline Initiators & $\begin{array}{l}\text { TNF- } \alpha \text {, FasL, or } \\
\text { TRAIL, infectious } \\
\text { pathogens }\end{array}$ & $\begin{array}{l}\text { Nutrient deprivation, } \\
\text { HDAC inhibitors, } \\
\text { hypoxia, } \\
\text { infectious pathogens }\end{array}$ & $\begin{array}{l}\text { TNF- } \alpha \text {, FasL, or TRAIL, } \\
\text { microbial infections } \\
\text { Ischemic injury }\end{array}$ & DAMPs, microbial infections & $\begin{array}{l}\text { Toxins, infections, } \\
\text { inflammation, } \\
\text { trauma }\end{array}$ \\
\hline $\begin{array}{l}\text { Intermediate } \\
\text { signalings }\end{array}$ & $\begin{array}{l}\text { Mitochondrial } \\
\text { pathway } \\
\text { Caspase-3, -6, } \\
\text {-7-dependent }\end{array}$ & $\begin{array}{l}\text { Caspase-independent } \\
\text { autophagosome for- } \\
\text { mation } \\
\text { Lysosomal protease }\end{array}$ & $\begin{array}{l}\text { TNF receptor signaling } \\
\text { JNK activation } \\
\text { Caspase-independent RIP1/ } \\
\text { RIP3 necrosome }\end{array}$ & $\begin{array}{l}\text { Nod-like receptors } \\
\text { Caspase 1-dependent } \\
\text { pyroptosome } \\
\text { Inflammasome }\end{array}$ & - \\
\hline $\begin{array}{l}\text { Terminal } \\
\text { cellular events }\end{array}$ & $\begin{array}{l}\text { Non-lytic cell shrink- } \\
\text { age } \\
\text { DNA fragmentation } \\
\text { apoptotic bodies }\end{array}$ & $\begin{array}{l}\text { Non-lytic autophagic } \\
\text { bodies }\end{array}$ & $\begin{array}{l}\text { Non-lytic, loss of plasma } \\
\text { membrane, swollen cellular } \\
\text { organelles }\end{array}$ & $\begin{array}{l}\text { Lytic, rapid loss of plasma } \\
\text { membrane, cell swelling, pore } \\
\text { formation }\end{array}$ & $\begin{array}{l}\text { Lytic, plasma } \\
\text { membrane rup- } \\
\text { ture, leak of } \\
\text { content }\end{array}$ \\
\hline $\begin{array}{l}\text { Inflammation } \\
\text { Immunogenicity }\end{array}$ & $\begin{array}{l}\text { Non-inflammatory } \\
+\end{array}$ & $\begin{array}{l}\text { Non-inflammatory } \\
+\end{array}$ & $\begin{array}{l}\text { Proinflammatory } \\
++\end{array}$ & $\begin{array}{l}\text { Proinflammatory } \\
++\end{array}$ & $\begin{array}{l}\text { Proinflammatory } \\
+++\end{array}$ \\
\hline $\begin{array}{l}\text { DAMPs } \\
\text { released }\end{array}$ & $\begin{array}{l}\text { Ecto-CRT HMGB1 } \\
\text { and ATP release }\end{array}$ & $\begin{array}{l}\text { HMGB1 and ATP } \\
\text { release }\end{array}$ & Long genomic DNA IL-6 & $\begin{array}{l}\text { HMGB1 and ATP release } \\
\text { IL- } 1 \alpha \text {, IL-1 } \beta, \text { IL- } 6 \text {, IL-18, and } \\
\text { TNF- } \alpha \text { chemokines }\end{array}$ & $\begin{array}{l}\text { HMGB1 and ATP } \\
\text { release } \\
\text { IL-1 } \alpha, \text { IL-33 } \\
\text { mRNA, and } \\
\text { genomic DNA }\end{array}$ \\
\hline Eat-me signals & Ecto-CRT & $\begin{array}{l}\text { LPC secretion } \\
\text { PS exposure }\end{array}$ & $\begin{array}{l}\text { LPC secretion } \\
\text { PS exposure }\end{array}$ & PS exposure & PS exposure \\
\hline
\end{tabular}

Abbreviations: TNF- $\alpha$, tumor necrosis factor- $\alpha$; FasL, Fas ligand; TRAIL, TNF-related apoptosis-inducing ligand; HDAC, histone deacetylase; IL- $1 \alpha$, interleukin- $1 \alpha$; IL-1 $\beta$, interleukin-1 $\beta$; IL-6, interleukin-6; IL-18, interleukin-18; IL-33, interleukin-33; ICD, immunogenic cell death; LPC, lysophosphatidylcholine; PS, phosphatidylserine; JNK, c-Jun N-terminal kinase.

The table gives a schematic overview of the multiple forms of cell death incuding apoptotic cell death (type 1 PCD), autophagic cell death (type 2 PCD), cell death induced by necroptosis (type 3 PCD), pyroptosis and necrosis. The extent of immunogenicity in each cell death subsection is scored as,,+++ and,+++ according to the expression levels of 'eat-me' signals and DAMPs emission. ICD in cancer can display different 'eat-me' signals, including ecto-CRT and LPC, on the cell membrane, as well as emission of DAMPs, ATP, and HMGB1. This peculiar ecto-CRT, which facilitates engulfment of TAAs from cancer cells by DCs, can only be found on cells that succumb to immunogenic apoptosis, whereas it is not present on cells dying in an immunologically silent manner. LPC secretion, PS exposure, and ATP release require autophagy induction. Numerous exquisite expression patterns shaped by the constituents of DAMPs and the interactive status of the immune system will predominantly determine the fate of subsequent immune responses, namely, immune tolerance or antitumor immunity

and shikonin effectively impede protumorigenic cytokine signaling. ${ }^{27}$ Shikonin has been found to induce type 1 or 3 PCD, which is determined by caspase- 8 activation as the 'decision-making switch'. ${ }^{39}$ On the other hand, type II ICD inducers, which preferentially target the ER, include hypericin-based photodynamic therapy (PDT) ${ }^{40,41,42}$ and oncolytic coxsackievirus B3 (CVB3). ${ }^{9}$ Hypericin-based PDT is an anticancer therapy that utilizes hypericin to induce reactive oxygen species (ROS) in the vicinity of the ER. ${ }^{43}$ Cancer cell infection with oncolytic viruses produce large amounts of viral proteins, which inevitably cause ER stress and ROS production to promote viral replication. ${ }^{44,45}$ The quality and/or quantity of ER stress linking ROS triggered by ICD inducers may determine the ICD properties. Indeed, the previous finding that rigorous ROS-mediated ER stress augmented the release of DAMPs revealed an unrecognized role of RNA-dependent protein kinase (PKR)-like ER kinase (PERK) as a constituent of mitochondria-associated ER membranes to exert ROS-mediated mitochondrial apoptosis. ${ }^{40,41,46}$ These observations indicate the superiority of type II ICD inducers with respect to immunological antitumor efficacies. However, further investigations to elucidate the precise interconnection between the ER stress and ROS production will be required to optimize antitumor immune responses.

\section{Calreticulin Exposure}

In response to specific chemotherapeutic agents, oncolytic viruses, and vorinostat, ecto-CRT has been found only on cells succumbing to immunogenic apoptosis. ${ }^{2,9,38}$ This 'eat-me' signal promotes phagocytosis by DCs, thereby facilitating their tumor antigen presentation and incitement of TAA-specific cytotoxic T cells. ${ }^{2,47}$ It has been shown that blockade of CRT inhibits phagocytosis of anthracycline-treated tumor cells by DCs and impairs their immunogenicity in mice..$^{2,47}$ In general, CRT exposure during ICD is an earlier process occurring within a few hours than PS externalization. ${ }^{48}$ The ecto-CRT induction capacity of ICD inducers has been shown to depend on the properties of ER stress and ROS production. ${ }^{2,37,49}$ Cancer cells can induce ecto-CRT followed by disturbance of the ER structure with GADD34 activation and PERK phosphorylation. It has been shown that depletion of PERK abolishes anthracycline-driven ecto-CRT and immunogenicity of cellular death (ER stress module), ${ }^{19}$ and that caspase- 8 acts upstream of apoptotic proteins Bax and Bak, and subsequent cleavage of its substrate Bap31 (apoptotic module) is indispensable for ecto-CRT induction. ${ }^{19}$ Furthermore, a direct interaction between ecto-CRT and ERp57 was shown to be required for their cotranslocation to the cell surface (Figure 1). ${ }^{29}$ Unlike the release of HMGB1 and ATP, 
Table 2 Classification of type I ICD inducers determined by their major targets to provoke antitumor responses

\begin{tabular}{|c|c|c|c|c|}
\hline Anticancer agents & $\begin{array}{l}\text { Type of cell } \\
\text { death induced }\end{array}$ & DAMPs & $\begin{array}{l}\text { Major targets by ICD } \\
\text { inducers }\end{array}$ & $\begin{array}{l}\text { Preclinical observations for inciting antitumor } \\
\text { immunity }\end{array}$ \\
\hline $\begin{array}{l}\text { Cytotoxic agents } \\
\text { (mitoxantrone, } \\
\text { oxaliplatin, } \\
\text { anthracyclines) }\end{array}$ & $\begin{array}{l}\text { Apoptosis, } \\
\text { autophagic cell } \\
\text { death, } \\
\text { necroptosis }\end{array}$ & $\begin{array}{l}\text { Ecto-CRT, ERp57, } \\
\text { HMGB1, and ATP } \\
\text { release }\end{array}$ & $\begin{array}{l}\text { Nucleus (DNA or DNA- } \\
\text { related proteins for cell } \\
\text { mitosis) }\end{array}$ & $\begin{array}{l}\text { In vivo antitumor effect is mitigated by depletion of } \\
\text { CD8 } \\
\text { T cells. Immunogenicity requires ecto-CRT in } \\
\text { prophylactic tumor vaccination mouse models. }\end{array}$ \\
\hline $\begin{array}{l}\text { Cyclophosphamide } \\
\text { (CTX) }\end{array}$ & Apoptosis & $\begin{array}{l}\text { Ecto-CRT, HMGB1 } \\
\text { release }\end{array}$ & Nucleus (DNA) & $\begin{array}{l}\text { Metronomic doses of CTX deplete Treg from bed } \\
\text { and tumors, CTX modulates DCs to produce IL-12 }\end{array}$ \\
\hline Shikonin & $\begin{array}{l}\text { Apoptosis, } \\
\text { necroptosis }\end{array}$ & Ecto-CRT, ecto-Hsp70 & $\begin{array}{l}\text { Cytosol (pyruvate kinase- } \\
\text { M2 protein) }\end{array}$ & $\begin{array}{l}\text { DCs incubated with shikonin increase Th1 cells } \\
\text { but decrease Treg cells }\end{array}$ \\
\hline Bortezomib & $\begin{array}{l}\text { Apoptosis, } \\
\text { autophagic cell } \\
\text { death }\end{array}$ & Ecto-Hsp90 & Cytosol (26S proteasome) & $\begin{array}{l}\text { Cytotoxicity of NK cells against bortezomib- } \\
\text { treated cells increased }\end{array}$ \\
\hline $\begin{array}{l}7 A 7 \text { (EGFR-specific } \\
\text { antibody) }\end{array}$ & Apoptosis & $\begin{array}{l}\text { Ecto-CRT, ERp57, } \\
\text { ecto-Hsp70, ectp- } \\
\text { Hsp90 }\end{array}$ & $\begin{array}{l}\text { Cell surface receptor } \\
\text { (EGFR) }\end{array}$ & $\begin{array}{l}\text { Contribution of } \mathrm{CD} 4^{+} \mathrm{T} \text { and } \mathrm{CD} 8^{+} \mathrm{T} \text { to } 7 \mathrm{~A} 7- \\
\text { triggered suppression of metastasis in mice model }\end{array}$ \\
\hline Cardiac glycosides & Apoptosis & $\begin{array}{l}\text { Ecto-CRT HMGB1 and } \\
\text { ATP release }\end{array}$ & $\begin{array}{l}\text { Cell surface }\left(\mathrm{Na}^{+} / \mathrm{K}^{+}-\right. \\
\text {ATPase, enzyme) }\end{array}$ & $\begin{array}{l}\text { Prophylactic antitumor immunity is partially } \\
\text { dependent on } \mathrm{CD}^{+} \mathrm{T} \text { cells accompanied with } \\
\text { Th17 cells }\end{array}$ \\
\hline UVC irradiation & $\begin{array}{l}\text { Apoptosis, } \\
\text { necroptosis, } \\
\text { necrosis }\end{array}$ & $\begin{array}{l}\text { Ecto-CRT and ERp57, } \\
\text { HMGB1 and ATP } \\
\text { release }\end{array}$ & Nucleus (DNA) & $\begin{array}{l}\text { UVC-treated cells increase susceptibility to attack } \\
\text { by NK cells and total splenocytes }\end{array}$ \\
\hline $\begin{array}{l}\text { Vorinostat (HDAC } \\
\text { inhibitor) }\end{array}$ & $\begin{array}{l}\text { Apoptosis } \\
\text { Autophagic cell } \\
\text { death }\end{array}$ & Ecto-CRT & $\begin{array}{l}\text { Nucleus (chromatin } \\
\text { structure) }\end{array}$ & $\begin{array}{l}\text { Promote the differentiation of } \mathrm{CD}^{+} \mathrm{T} \text { cells to } \\
\text { memory cells }\end{array}$ \\
\hline
\end{tabular}

Abbreviations: Ecto-CRT, calreticulin exposure; DAMPs, damage-associated molecular patterns; ICD, immunogenic cell death, HMGB1; high-mobility group protein B1; Hsp, heat-shock protein; Treg, regulatory T cells; DCs, dendritic cells; IL-12, interleukin-12; NK, natural killer; EGFR, epidermal growth factor receptor; ATP, adenosine triphosphate; UVC, ultraviolet C

Table 3 Classification of type II ICD inducers determined by their major targets to provoke antitumor responses

\begin{tabular}{|c|c|c|c|c|}
\hline Anticancer agents & $\begin{array}{l}\text { Type of cell death } \\
\text { induced }\end{array}$ & DAMPs & $\begin{array}{l}\text { Major } \\
\text { targets by } \\
\text { ICD } \\
\text { inducers }\end{array}$ & $\begin{array}{l}\text { Preclinical observations for inciting } \\
\text { antitumor immunity }\end{array}$ \\
\hline PDT with hypericin & $\begin{array}{l}\text { Apoptosis, autophagic } \\
\text { cell death dependent on } \\
\text { Bax/Bak, necroptosis }\end{array}$ & $\begin{array}{l}\text { Ecto-CRT, ecto- } \\
\text { Hsp70, ectp-Hsp90, } \\
\text { HMGB1, and ATP } \\
\text { release }\end{array}$ & $\begin{array}{l}\text { ER (ROS } \\
\text { generation) }\end{array}$ & $\begin{array}{l}\text { PDT -hypericin therapy provokes antitumor } \\
\text { immunity in both prophylactic and therapeutic } \\
\text { murine tumor models. Same therapy-treated } \\
\text { tumor cells result in phenotypic maturation of } \\
\text { DCs and robust CD4 }{ }^{+} \text {T and CD8 }{ }^{+} T \text { cell } \\
\text { expansion }\end{array}$ \\
\hline CVB3 & Apoptosis & $\begin{array}{l}\text { Ecto-CRT, HMGB1 } \\
\text { translocation, ATP } \\
\text { release }\end{array}$ & $\begin{array}{l}\text { ER (ROS } \\
\text { generation) }\end{array}$ & $\begin{array}{l}\text { Intratumoral CVB3 administration markedly } \\
\text { recruited NK cells and granulocytes, both of } \\
\text { which contribute to the antitumor effects as } \\
\text { shown by depletion assays, macrophages, and } \\
\text { mature DCs into tumor tissues }\end{array}$ \\
\hline $\begin{array}{l}\text { Ad5/3-hTERT-E1A-hCD40L: } \\
\text { chimeric Ad5/3 capsid, an } \\
\text { hTERT promoter and human } \\
\text { CD40L }\end{array}$ & Apoptosis & $\begin{array}{l}\text { Ecto-CRT, HMGB1 } \\
\text { release, ATP release }\end{array}$ & $\begin{array}{l}\text { ER (ROS } \\
\text { generation) }\end{array}$ & $\begin{array}{l}\text { In two syngeneic mouse models, murine CD40L } \\
\text { induced activation of APCs, leading to increased } \\
\text { IL- } 12 \text { production in splenocytes, associated with } \\
\text { induction of the Th1 cytokines IFN- } \gamma \text {, RANTES, } \\
\text { and TNF- } \alpha \text {. Tumors treated with Ad5/3-CMV- } \\
\text { mCD40L displayed an enhanced presence of } \\
\text { macrophages and cytotoxic CD8 }{ }^{+} \text {T cells }\end{array}$ \\
\hline Edmonston strain MV & Apoptosis & $\begin{array}{l}\text { IL-6 production, } \\
\text { HMGB1 release }\end{array}$ & $\begin{array}{l}\text { ER (ROS } \\
\text { generation) }\end{array}$ & $\begin{array}{l}\text { Coculture of MV-infected melanoma cells with } \\
\text { human DCs led to both CD80 and CD } 66 \\
\text { upregulation on them. CD } 8^{+} \mathrm{T} \text { cells cocultured } \\
\text { with tumor cell-loaded and MV-infected DCs } \\
\text { degranulated CD } 107 \text { a to target tumor cells with } \\
\text { functional killing activity }\end{array}$ \\
\hline
\end{tabular}

Abbreviations: PDT, photodynamic therapy; CVB3, coxasackievirus B3; MV, measles virus; ROS, reactive oxygen species; ER, endoplasmic reticulum; hTERT, telomerase reverse transcriptase; hCD40L, human CD40 ligand; Th1, T helper type 1; RANTES, regulated and normal T cell expressed and secreted; TNF- $\alpha$, tumor necrosis factor- $\alpha$; IL- 6 , interleukin- 6 
ecto-CRT could be one of the determinants that distinguishes between immunogenic and non-immunogenic cell death. ${ }^{47}$

\section{HMGB1}

HMGB1, one of the DAMPs, is a DNA-binding protein originally known as a nuclear non-histone chromatin-binding protein. ${ }^{50}$ Although extracellular HMGB1 had been deemed to be released mainly from the nucleus during necrosis, ${ }^{42}$ it was found to be excreted from cells undergoing late stage of apoptosis and autophagy. ${ }^{30,51}$ HMGB1 inhibition in cancers undergoing immunogenic apoptosis impaired their ability to incite antitumor immunity in a prophylactic vaccination model. ${ }^{30}$ HMGB1 initiates potent inflammation by stimulating the production of proinflammatory cytokines ${ }^{52}$ from APCs via its binding to different surface receptors including receptor for advanced glycation end-products (RAGE), TLR2, TLR4, TLR9, and TIM3 (Figure 1). ${ }^{53,54}$ Importantly, the binding of HMGB1 to TLR4 on APCs was required to suppress tumor development, which is consistent with clinical study showing that breast cancer patients harboring a single-nucleotide polymorphism (Asp299Gly) in the TLR4 gene undergo an early relapse after anthracycline treatment. ${ }^{30,55,56}$ In contrast, secreted HMGB1 could induce a protumor inflammation to facilitate tumor progression. ${ }^{57}$ In addition, HMGB1 expression is significantly associated with overall survival of patients with bladder cancer. ${ }^{58}$ As HMGB1 is an intrinsic sensor of oxidative stress, ${ }^{59}$ the immunomodulatory properties of HMGB1 might be determined by its redox status. ${ }^{60,61}$ Indeed, reduced HMGB1 production from dying cells was shown to trigger the immunogenic DCs, whereas oxidized HMGB1 during apoptosis fails. ${ }^{51}$ As the extracellular space is usually oxidative under physiological conditions but is unpredictably variable under pathogenic conditions, ${ }^{62}$ the unstable redox status of the tumor microenvironment might account for these inconsistent findings. However, the observation that the tumor microenvironment tends to be pro-oxidative ${ }^{63}$ implies that a therapeutic approach using antioxidants to decrease ROS production would be favorable to stimulate antitumor immunity. Importantly, many anticancer agents, including chemotherapy, ${ }^{30}$ radiation, ${ }^{22}$ or oncolytic viruses, ${ }^{9,64,65}$ have been shown to induce HMGB1 release from cancer cells, highlighting the significance of further addressing the mechanism of how these modalities affect the redox status of HMGB1.

\section{Adenosine Triphosphate}

Extracellular ATP released from apoptotic cells is another important factor in ICD induction. ATP signaling recognized by P2Y2 receptors on phagocytes as a 'find-me' signal enables

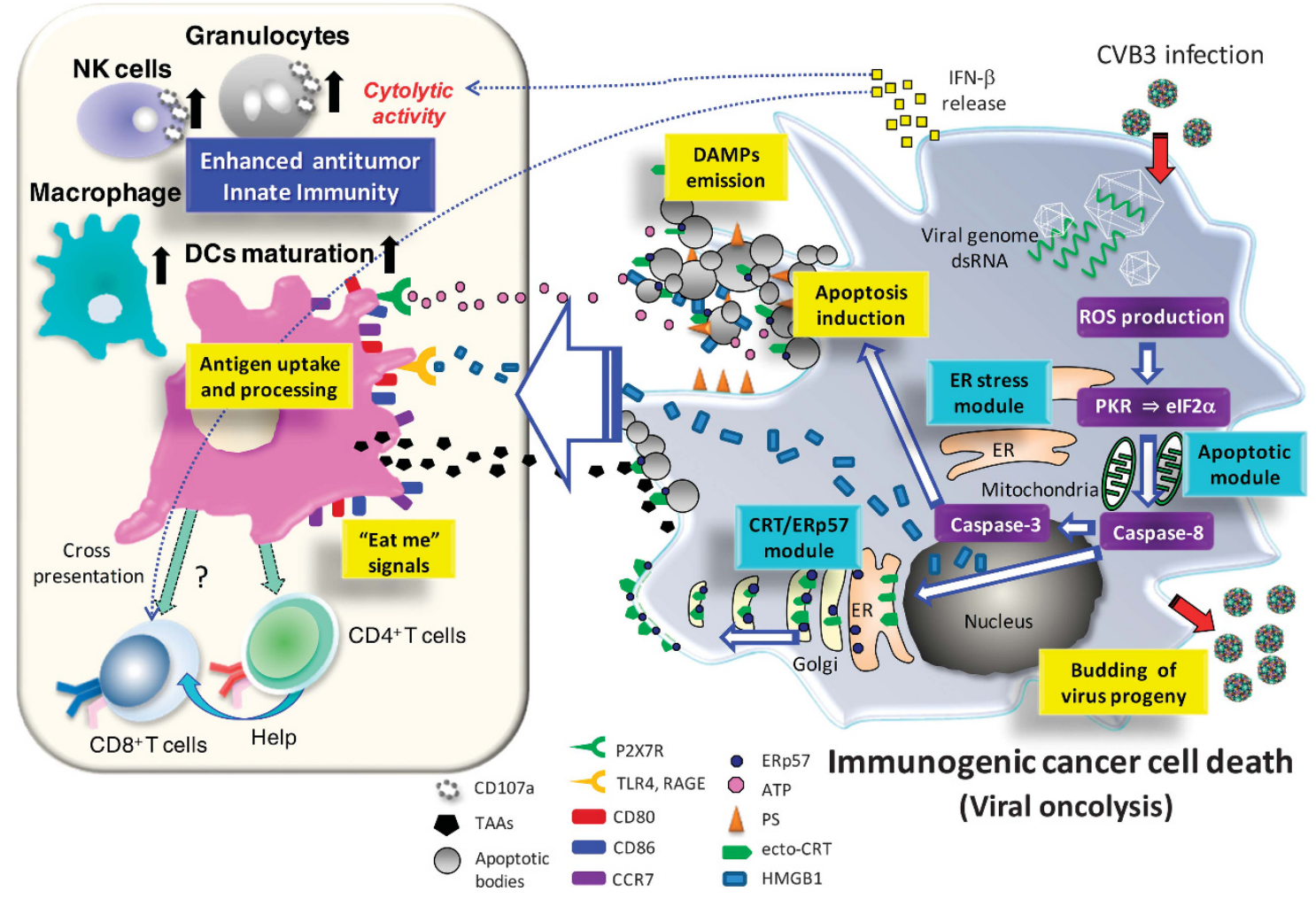

Figure 1 Oncolytic virus (CVB3) infection-triggered cancer cell death induces innate immune cell-mediated antitumor immunity. Intratumoral CVB3 infection-activated natural killer (NK) cells and granulocytes with enhanced expression of CD107a, a cytolytic degranulation marker, have been found to contribute to substantial antitumor effects as evidenced by NK cell and granulocyte depletion assays. Upon CVB3 infection, tumor cells can partially induce ecto-CRT on human tumor cells during early apoptosis, whereas majority of other viruses subvert ICD by circumventing ecto-CRT induction, and followed by robust release of DAMPs, including ATP and HMGB1, during later stages of cell death, which facilitates maturation of DCs via binding to Toll-like receptor 4 (TLR4)/RAGE and $P_{2} \times{ }_{7} R$, respectively. Viral genomes and/or viral progenies also stimulate DCs for their activation. Mature DCs may then efficiently phagocytose TAAs simultaneously released from dying cells and ultimately cross-present them to $\mathrm{CD} 8^{+} \mathrm{T}$ cells with the support with $\mathrm{CD}^{+}{ }^{+} \mathrm{T}$ cells to elicit substantial antitumor immunity. Although ATP secretion relies on autophagic machinery, the other forms of cancer cell death, such as autophagic cell death and necroptosis, triggered by CVB3 infection have not yet been fully investigated 
them to migrate into inflamed sites. ${ }^{66}$ Indeed, ATP released from cancer cells treated with chemotherapeutic agents is essential for effective antitumor immune responses. ${ }^{67}$ In addition, small interfering RNA-mediated inhibition of autophagic machinery abolishes ATP release from chemotherapy-treated tumor cells and mitigates the antitumor response. $^{68}$ Radiotherapy triggers ATP release from dying tumor cells through its interaction with the $\mathrm{P} 2 \times 7$ purinergic receptor, ${ }^{69}$ possibly resulting in the activation of the NLRP3-ASC-inflammasome axis and subsequent secretion of $\mathrm{IL}-1 \beta$. $^{70}$

We and others recently showed that oncolytic viruses induce secretion of extracellular ATP from human cancer cells (Figure 1). ${ }^{9,65}$ Unlike ecto-CRT induction, the release of ATP and HMGB1 is triggered by a range of death-inducing stimuli, and is not restricted to induction in apoptotic cell death. ${ }^{47}$ Although ATP production is required for efficient vaccinia virus production ${ }^{71}$ and facilitates HIV infection through its interaction with $\mathrm{P} 2 \mathrm{Y} 2$ receptors, ${ }^{72}$ there is little knowledge of how oncolytic viruses provoke ATP release.

\section{Autophagic Cell Death}

Autophagy physiologically has catabolic roles, particularly in cell survival. ${ }^{73}$ However, persistent autophagy causes a caspase-independent form of cell death that is, morphologically defined as autophagic cell death (ACD), termed as type 2 PCD, through lysosomal proteinase-regulated elimination of cellular organelles. ${ }^{74,75}$ Autophagy sometimes directs itself to cellular death, either in cooperation with apoptosis or as a back-up system, and thus is deemed as a cellular program with a 'double-faced' role.

Interestingly, the key molecules of autophagy and apoptosis pathways are intricately intertwined with shared several molecules including regulatory genes such as $p 53$ and $p_{19 A R F}{ }^{76}$ This crosstalk therefore can be viewed as a significant clue to understand the fate of dying cancer cells from therapeutic view points. Although ACD occurs without chromatin condensation but with massive autophagic vacuolization, ${ }^{77}$ autophagy, often disabled in cancer, has been shown to be required for induction of immunogenicity. ${ }^{68}$ First, dying cells in embryoid bodies that lack autophagy-related gene are unable to express the 'eat-me' signals and secrete lower levels of the 'come-get-me' signal, lysophosphatidylcholine. $^{78}$ Second, autophagy deficiency hinders ATP secretion from dying cancer cells, resulting in the impairment of DC recruitment and formation of adaptive immunity responses (Table 1). ${ }^{68}$ Third, the inability of autophagydeficient cancer cells to provoke antitumor immunity after chemotherapy can be reverted by suppression of extracellular ATP-degrading enzymes. ${ }^{68,79}$ Therefore, immunogenicity of ACD could be mediated by subtle spatiotemporal alterations in the treated cancer cells.

Novel strategy of autophagy inhibition is therapeutically effective for eliminating apoptosis-resistant cancer cells based on the rationale that growing tumors may harness autophagy as an adaptation to resist therapeutic stresses. $^{80,81,82}$ Hence, more efforts should be made to elucidate the intricate interaction between autophagy inhibition and resulting effects on the immunogenicity.

\section{Necrotic Cell Death and Necroptosis}

Necrotic cell death is induced by external factors such as toxins, cancer, infections, and trauma, and is morphologically characterized by cellular swelling, rupture of the plasma membrane, and loss of cytoplasmic contents. ${ }^{83}$ Understanding the immunogenicity of necrotic cell death is becoming important because it frequently induces robust inflammatory reactions to mount protective immune responses (Table 1). ${ }^{84,85,86}$ Although necrosis has long been viewed as non-PCD, its execution was shown to be controlled by specific signal-transduction pathways and catabolic mechanism. ${ }^{87,88,89}$ This alternative form of necrotic PCD, aptly termed necroptosis (type 3 PCD), is induced by tumor necrosis factor (TNF) receptor signaling that involves activation of the receptor-interacting protein (RIP) family. Upon inhibition of apoptotic pathway by the caspase inhibitor, activation of RIP1 and RIP3 kinase leads to mitochondrial instability and cell death. ${ }^{90,91}$ Phosphorylated RIP1 and RIP3 generate a molecular complex called the necrosome, which initiates necroptosis. ROS production under necroptosis has been shown to facilitate TNF- $\alpha$-induced cell death by sustaining c-Jun $\mathrm{N}$-terminal kinase activation. ${ }^{92}$ Intriguingly, necroptosis can also be executed via stimulation by apoptosis-inducible ligands such as TNF- $\alpha$, FasL, or TRAIL (Table 1). Notably, cytotoxic agents are shown to induce necrotic cell death in apoptosis-defective cancer cells, ${ }^{93}$ probably because necroptosis is principally induced when a cell cannot die via apoptotic pathways. ${ }^{94}$ On the other hand, conventional therapy-resistant cancer stem cells (CSCs) have a higher antiapoptotic activity than that of their counterparts. ${ }^{95,96}$ Therefore, it would be vital to clarify the key machinery of not only the necroptosis induction in cancer cells for CSC-directed therapeutic application but also the resultant immunogenicity to modulate antitumor immunity.

\section{Pyroptosis}

Pyroptosis is a recently indentified form of PCD stimulated by microbial infections and non-infectious stimuli such as myocardial infarction and cancer. In contrast to apoptosis, pyroptosis is uniquely mediated by caspase-1 activity triggered by the formation of a cytosolic complex termed the 'inflammasome', resulting in highly inflammatory outcomes (Table 1). Pyroptotic cells represent morphological characteristics, some of which are shared with apoptosis and necrosis. ${ }^{97}$ The function of activated caspase- 1 is to cleave proteolytically the proforms of the proinflammatory cytokines, IL-1 $\beta$ and IL-18, to their active forms. ${ }^{97}$ Although pyroptosis has been intensively studied in the context of bacteria-infected macrophages, ${ }^{98}$ it can also be triggered in human cancer cells infected with recombinant herpes simplex virus 2 (HSV-2) (Table 4). ${ }^{99}$ Pyroptotic cancer cells induced by microbial infection have been recently shown to facilitate phagocytosis by macrophages, presumably through their PS exposure and ATP release. ${ }^{100}$ Accordingly, the caspase-1-dependent generation of proinflammmatory cytokines and other DAMPs could be essential factors to provide a suitable inflammation for ICD induction. 
Table 4 DNA oncolytic viruses and their differential properties to induce either multiple forms of cell death or antitumor immunity

\begin{tabular}{|c|c|c|c|c|}
\hline Oncolytic viruses & Type of cancer cells & $\begin{array}{l}\text { Type of cell death } \\
\text { induced }\end{array}$ & DAMPs & $\begin{array}{l}\text { Possible mechanism of } \\
\text { antitumor immunity }\end{array}$ \\
\hline $\begin{array}{l}\text { hTERT-Ad: CRAds regulated by } \\
\text { human hTERT promoter }\end{array}$ & $\begin{array}{l}\text { Human glioma, cervical and } \\
\text { prostate cancer }\end{array}$ & Autophagy & NA & NA \\
\hline hTERT-Ad & Human lung cancer & $\begin{array}{l}\text { Autophagy via } \\
\text { E2F1-miR-7- } \\
\text { EGFR }\end{array}$ & NA & NA \\
\hline OBP-702: p53-armed hTERT-Ad & Human osteosarcoma & $\begin{array}{l}\text { Apoptosis } \\
\text { Autophagy }\end{array}$ & NA & NA \\
\hline $\begin{array}{l}\text { CRAd-S-RGD: Ad5 carrying the RGD } \\
\text { motif and survivin promoter }\end{array}$ & Human glioma cells & Autophagy & NA & NA \\
\hline $\begin{array}{l}\text { Ad5/3-hTERT-E1A-hCD40L: } \\
\text { chimeric Ad5/3 capsid with hTERT } \\
\text { promoter }\end{array}$ & $\begin{array}{l}\text { Murine urothelial } \\
\text { carcinoma, melanoma }\end{array}$ & Apoptosis & $\begin{array}{l}\text { Ecto-CRT, ATP and } \\
\text { HMGB1 }\end{array}$ & $\begin{array}{l}\text { Enhanced recruitment of } \\
\text { macrophages and CD8 } \\
\text { T cells }\end{array}$ \\
\hline $\begin{array}{l}\text { ZD55-IFN- } \beta \text { : Oncolytic adenovirus } \\
\text { carrying IFN- } \beta\end{array}$ & $\begin{array}{l}\text { Human hepatoma, breast } \\
\text { cancer }\end{array}$ & $\begin{array}{l}\text { Apoptosis } \\
\text { Necroptosis }\end{array}$ & NA & NA \\
\hline Vaccinia virus & $\begin{array}{l}\text { Human colon, breast, } \\
\text { ovarian cancer }\end{array}$ & $\begin{array}{l}\text { Not apoptosis } \\
\text { Possibly necrosis }\end{array}$ & HMGB1 release & NA \\
\hline $\begin{array}{l}\text { VSP: antiapoptosis genes, } \\
\text { SPI- } 1 \text { - and SPI-2-deleted } \\
\text { vaccinia virus }\end{array}$ & $\begin{array}{l}\text { Murine colon } \\
\text { adenocarcinoma }\end{array}$ & $\begin{array}{l}\text { Apoptosis } \\
\text { Necrosis }\end{array}$ & HMGB1 release & NA \\
\hline HSV2: Human simplex virus 2 & Human endometrial cancer & $\begin{array}{l}\text { Apoptosis } \\
\text { Necrosis }\end{array}$ & HMGB1 release & NA \\
\hline $\begin{array}{l}\text { HSV-1716: a replication-restricted } \\
\text { mutant herpes simplex virus }\end{array}$ & Murine ovarian cancer & NA & NA & $\begin{array}{l}\text { Intratumoral injection } \\
\text { induced IFN- } \gamma \text {, } \\
\text { CXCL9 and CXCL10 with } \\
\text { increase } \\
\text { in NK and CD8 }{ }^{+} \\
\text {T cells }\end{array}$ \\
\hline $\begin{array}{l}\text { HSV-2 mutant } \triangle \mathrm{PK} \text { : ICP10PK-deleted } \\
\text { HSV-2 virus }\end{array}$ & Human melanoma cells & $\begin{array}{l}\text { Apoptosis } \\
\text { Pyroptosis }\end{array}$ & NA & $\begin{array}{l}\text { Dominant induction of } \\
\text { CD4 }{ }^{+} \text {Th1 cells }\end{array}$ \\
\hline
\end{tabular}

Abbreviations: hTERT, telomerase reverse transcriptase; CRAds, conditionally replicative adenoviruses; miR-7, microRNA-7, EGFR, epidermal growth factor receptor, ecto-CRT, calreticulin exposure; DAMPs, damage-associated molecular patterns; ICD, immunogenic cell death, HMGB1; high-mobility group protein B1;ATP, adenosine triphosphate; IFN- $\beta$, interferon- $\beta$; HSV, herpes simplex virus; IFN- $\gamma$, interferon- $\gamma$; CXCL9, chemokine (C-X-C motif) ligand 9; CXCL10, chemokine (C-X-C motif) ligand 10; NK, natural killer cells; NA, not assessed; Th1, T helper type 1

\section{DAMPs Induced by Infection with Oncolytic Viruses}

Because oncolytic viral infection can produce abundant PAMPs, including viral proteins and nucleic acids, followed by the release of DAMPs and the entire repertoire of TAAs from treated tumors, ${ }^{101}$ oncolytic virus-triggered ICD may be more effective for induction of antitumor immunity. As viruses have developed sophisticated machineries to evade apoptotic cell death and interfere with ER stress and autophagy responses for their survival, ${ }^{102,103}$ ICD may have played an essential role in the everlasting war between viruses and their hosts. We and other groups have found that many oncolytic viruses can induce apoptotic cell death and/or necrosis in cancer cells, ${ }^{9,104,105,106}$ supporting their immunostimulatory potential to augment antitumor efficacy (Tables 4 and 5). ${ }^{107,108}$ CVB3 infection induces multiple DAMPs including ecto-CRT, HMGB1 translocation from nuclei, and ATP release from human lung cancer cells. Importantly, intratumoral CVB3 administration can prominently recruit cytolytic degranulation marker CD107a-mobilized NK cells and granulocytes, and mature DCs into the tumor bed (Figure 1). ${ }^{9,27}$ As pathogenic viruses have developed their strategies to subvert ecto-CRT and circumvent ICD induction, ${ }^{109}$ it is noteworthy that CVB3 infection can induce
ecto-CRT accompanied by other DAMPs. ${ }^{9}$ Furthermore, we demonstrated that both NK cells and granulocytes substantially contributed to the CVB3-mediated antitumor efficacy as evidenced by in vivo depletion assays. ${ }^{9}$

Upon intratumoral replication of oncolytic viruses, resultant alterations in tumor microenvironment may restore the compromised antitumor immunity, presumably through induction of IFNs and/or cytokines that activate NK cells and APCs. ${ }^{110,111}$ Although tumor-infiltrating DCs were impaired at maturation by immunosuppressive IL-10, $P G E_{2}$, and transforming growth factor $\beta$ produced from tumor cells, ${ }^{112}$ unidentified components in the culture media from reovirus-infected cancer cells facilitated maturation of DCs. ${ }^{113}$

Recent studies delineated that oncolytic viruses such as vaccinia, measles, HSV-2, and adenovirus cause the release of HMGB1. ${ }^{64,65,114,115,116,117}$ Although HMGB1 interacts with viral components and may modulate viral replication, ${ }^{117}$ the molecular mechanisms of how each oncolytic virus differentially produces these DAMPs remain largely elusive.

\section{Multimodal PCD Induced by Oncolytic Viruses}

We showed that approximately $20 \%$ of CVB3-mediated cytotoxicity of A549 cells resulted from apoptotic cell death. ${ }^{9}$ 
Table 5 RNA oncolytic viruses and their differential properties to induce either multiple forms of cell death or antitumor immunity

\begin{tabular}{|c|c|c|c|c|}
\hline Oncolytic viruses & $\begin{array}{l}\text { Type of } \\
\text { cancer cells }\end{array}$ & $\begin{array}{l}\text { Type of cell } \\
\text { death } \\
\text { induced }\end{array}$ & DAMPs & Possible mechanism of antitumor immunity \\
\hline Edmonston vaccine strain of MV & $\begin{array}{l}\text { Human } \\
\text { melanoma }\end{array}$ & NA & IL-6 HMGB1 release & $\begin{array}{l}\text { Human DC maturation Priming an adaptive } \\
\text { T-cell response }\end{array}$ \\
\hline MV-NPL: genetically engineered MV & $\begin{array}{l}\text { Human renal } \\
\text { cell carcinoma }\end{array}$ & Apoptosis & NA & NA \\
\hline $\begin{array}{l}\text { MV-CEA:Edmonston vaccine MV } \\
\text { genetically engineered to produce } \\
\text { CEA antigen }\end{array}$ & $\begin{array}{l}\text { Human breast } \\
\text { cancer }\end{array}$ & Apoptosis & NA & NA \\
\hline CVB3 & $\begin{array}{l}\text { Human non- } \\
\text { small-cell lung } \\
\text { cancer }\end{array}$ & Apoptosis & $\begin{array}{l}\text { Preapoptotic } \\
\text { ecto-CRT, HMGB1 } \\
\text { translocation, ATP } \\
\text { release }\end{array}$ & $\begin{array}{l}\text { Phenotypic activation of immature DCs and } \\
\text { lytic } \\
\text { NK cells in tumors. Deletion of NK and } \\
\text { granulocytes abrogated the CVB3-induced } \\
\text { in vivo antitumor } \\
\text { immunity }\end{array}$ \\
\hline NDV & Human glioma & Autophagy & NA & NA \\
\hline Reovirus & $\begin{array}{l}\text { Human multiple } \\
\text { myeloma }\end{array}$ & $\begin{array}{l}\text { Apoptosis } \\
\text { Autophagy }\end{array}$ & NA & NA \\
\hline Live-attenuated poliovirus & $\begin{array}{l}\text { Human } \\
\text { neuroblastoma }\end{array}$ & Apoptosis & NA & NA \\
\hline M51R: M protein mutant VSV & $\begin{array}{l}\text { Human } \\
\text { glioblastoma } \\
\text { multiforme }\end{array}$ & Apoptosis & NA & NA \\
\hline Interferon-sensitive VSV (AV3 strain) & $\begin{array}{l}\text { Human } \\
\text { prostate cancer }\end{array}$ & Apoptosis & NA & NA \\
\hline
\end{tabular}

Abbreviations: MV, measles virus; CVB3, coxasackievirus B3; NDV, New castle disease virus; CEA, carcinoembryonic antigen; VSV, vesicular stomatitis virus

This induction was presumably due to the capacity of CVB3 infection to induce PKR-mediated phosphorylation of elF2 and caspase-8-mediated activation of proapoptotic mediator, caspase-3 (Figure 1). ${ }^{118,119}$ Other DNA and RNA oncolytic viruses have been reported to induce apoptotic cancer cell death (Tables 4 and 5). However, there are only two reports showing that virus-induced ecto-CRT was correlated with enhanced intratumoral infiltrations of immune subpopulations, which accounted for the 'in vivo' remarkable antitumor immunity. ${ }^{9,65}$

Several studies showed that recombinant oncolytic adenoviruses induced ACD in human malignant glioma cells, ${ }^{120}$ brain tumor stem cells, ${ }^{121}$ osteosarcoma cells, ${ }^{105}$ and lung cancer cells. ${ }^{122}$ Newcastle disease virus also triggered autophagy in glioma cells to promote its viral replication. ${ }^{123}$ Reovirus-mediated oncolysis of multiple myeloma was reported to be orchestrated via upregulation of autophagy. ${ }^{124}$ Because cancer cells are largely refractory to apoptotic inducers but vulnerable to necroptosis, ${ }^{39}$ overcoming anticancer drug resistance may be achieved by activation of necroptotic rather than apoptotic pathways, where the former might be the intrinsic 'Achilles heel' of cancers. ${ }^{125}$ So far only recombinant adenovirus has been shown to facilitate both necroptotic and apoptotic cell death with a synergistic effect on cancer cells when combined with doxorubicin (Tables 4 and 5). ${ }^{126}$ In addition, most oncolytic viruses may induce pyroptotic cancer cell death accompanied by abundant proinflammatory cytokines and DAMPs. Accordingly, some oncolytic viruses may induce multimodal
$I C D$, allowing them to be a plausible modality as promising agents of immunotherapy.

\section{Strategies to Enhance the Potentials of ICD Induced by Oncolytic Viruses}

Besides DAMPs, massive production of type I IFNs (IFN- $\alpha / \beta)$ upon oncolytic viral infection can be a potent immunomodulator through their indirect immunostimulatory effects on neutrophils and T cells, ${ }^{127,128}$ as well as through their direct antiproliferative effects. ${ }^{129}$ Despite a creation of multimodal ICD by oncolytic viruses to facilitate antitumor immunity, much attention should be paid to the preferential antiviral immunity that might impede direct viral oncolysis-mediated tumor destruction. To avoid this, cyclophosphamide is shown to retard immune removal of oncolytic viruses, enhancing the persistence of viral infection. ${ }^{130}$ Another promising strategy to overcome antiviral immunity could be potentiating immune responses by gene modification of oncolytic viruses to arm them with immunostimulatory cytokines, such as GM-CSF, IL-2, IL-12, and IL-15. Indeed, the results of clinical trials of the GM-CSF gene-harboring oncolytic vaccinia virus JX-594 and the GM-CSF gene-harboring oncolytic herpes virus talimogene laherparepvec demonstrated that a clinical benefit can be accomplished by combined respective oncolytic activity with the recruitment of immune cells. ${ }^{6,7,131}$ The combination of adoptive T-cell therapy with oncolytic viruses is shown to elicit an increased antitumor effect. ${ }^{131,132}$ Collectively, the design of combinatorial therapies of oncolytic viruses with immunotherapeutic modalities may 
hold the key to mount maximally a multifaceted attack against cancers.

\section{Conclusions}

Although mechanism of ICD induction is a very complicated process, we need to elucidate how dying cells become much more stimulatory in shaping antitumor immune responses than was ever expected. Notably, intermediate death processes, including caspase activation, mitochondrial degradation by autophagy, ROS production, and oxidative modification of DAMPs, have been found to fine-tune the balance between antitumor tolerance and immunity, providing implications in manipulation of ICD.

Four forms of PCD, apoptosis, autophagy, necroptosis, and pyroptosis, may jointly decide the fate of cells of malignant cells. However, in terms of immunogenicity, investigations of only apoptotic cell death in cancer cells have just begun. Therefore, further elucidation of determinants of respective PCD-inducing pathway and characterization of resultant ICD should aid to develop novel anticancer strategies. A recent review advocates a list of characteristics for an ideal ICD inducer, ${ }^{27}$ as follows: (1) efficiently activates apoptosis or necrosis leading to emission of multiple DAMPs and TLR agonists; ${ }^{133,134}$ (2) irrelevant in drug-efflux pathways; ${ }^{135}$ (3) can induce ER stress; ${ }^{134}$ (4) has negligible suppressive or inhibitory effects on immune cells: ${ }^{136}$ (5) counteracts immunosuppressive responses; ${ }^{136,137}$ and (6) directly targets not only the primary tumor but also metastases. ${ }^{138}$ No ideal ICD inducer exists, but it is important to seek for ideal combinatorial therapies that could achieve these properties. Of the currently known relevant ICD inducers, those that meet most of these properties include mitoxantrone, hypericin-PDT, and shikonin. However, diverse oncolytic viruses could be the promising ICD inducer as we gain more knowledge about the properties yet to be investigated. Evidently, they can destroy conventional therapy-resistant CSCs, ${ }^{139}$ possibly through their ability to induce distinctive PCD and/or modification to express genes that target CSC-specific signaling pathways underpinning their cell survival. $^{140}$

Gaining more detailed insights into the mechanisms of ICD induction, to be perceived by the immune system, will not only ameliorate the development of promising anticancer agents or combinatorial therapies but also offer useful knowledge in various life science fields including virology, immunology, and clinical medicine.

\section{Conflict of Interest}

The authors declare no conflict of interest.

Acknowledgements. This work was supported by grants from the Ministry of Education, Culture, Sports, Science, and Technology (17016053 and 23240133), and the Ministry of Health Labour and Welfare (23080101), Japan.

1. Casares N, Pequignot MO, Tesniere A, Ghiringhelli F, Roux S, Chaput N et al. Caspase-dependent immunogenicity of doxorubicin-induced tumor cell death. J Exp Med 2005; 202: 1691-1701.
2. Obeid M, Tesniere A, Ghiringhelli F, Fimia GM, Apetoh L, Perfettini JL et al. Calreticulin exposure dictates the immunogenicity of cancer cell death. Nat Med 2007; 13: 54-61.

3. Thompson CB. Apoptosis in the pathogenesis and treatment of disease. Science 1995; 267: 1456-1462.

4. Garg AD, Krysko DV, Verfaillie T, Kaczmarek A, Ferreira GB, Marysael T et al. A novel pathway combining calreticulin exposure and ATP secretion in immunogenic cancer cell death. EMBO J 2012; 31: 1062-1079.

5. Tanimoto T, Hori A, Kami M. Sipuleucel-T immunotherapy for castration-resistant prostate cancer. N Engl J Med 2010; 363: 1967-1968; 1966; author reply.

6. Senzer NN, Kaufman HL, Amatruda T, Nemunaitis M, Reid T, Daniels G et al. Phase II clinical trial of a granulocyte-macrophage colony-stimulating factor-encoding, second-generation oncolytic herpesvirus in patients with unresectable metastatic melanoma. J Clin Oncol 2009; 27: 5763-5771.

7. Heo J, Reid T, Ruo L, Breitbach CJ, Rose S, Bloomston M et al. Randomized dose-finding clinical trial of oncolytic immunotherapeutic vaccinia JX-594 in liver cancer. Nat Med 2013; 19: 329-336.

8. Sobol PT, Boudreau JE, Stephenson K, Wan Y, Lichty BD, Mossman KL. Adaptive antiviral immunity is a determinant of the therapeutic success of oncolytic virotherapy. Mol Ther 2011; 19: 335-344.

9. Miyamoto $S$, Inoue $H$, Nakamura $T$, Yamada $M$, Sakamoto $C$, Urata $Y$ et al. Coxsackievirus B3 is an oncolytic virus with immunostimulatory properties that is active against lung adenocarcinoma. Cancer Res 2012; 72: 2609-2621.

10. Contag CH, Sikorski R, Negrin RS, Schmidt T, Fan AC, Bachireddy P et al. Definition of an enhanced immune cell therapy in mice that can target stem-like lymphoma cells. Cancer Res 2010; 70: 9837-9845.

11. Russell SJ, Peng KW, Bell JC. Oncolytic virotherapy. Nat Biotechnol 2012; 30: 658-670. 12. Curtin JF, Cotter TG. Apoptosis: historical perspectives. Essays Biochem 2003; 39: 1-10.

13. Galluzzi L, Vitale I, Abrams JM, Alnemri ES, Baehrecke EH, Blagosklonny MV et al. Molecular definitions of cell death subroutines: recommendations of the Nomenclature Committee on Cell Death 2012. Cell Death Differ 2012 19: 107-120.

14. Brenner C, Kroemer G. Apoptosis. Mitochondria-the death signal integrators. Science 2000; 289: 1150-1151.

15. Elmore S. Apoptosis: a review of programmed cell death. Toxicol Pathol 2007; 35: 495-516.

16. Chen W, Frank ME, Jin W, Wahl SM. TGF-beta released by apoptotic T cells contributes to an immunosuppressive milieu. Immunity 2001; 14: 715-725.

17. Krysko DV, Kaczmarek A, Krysko O, Heyndrickx L, Woznicki J, Bogaert P et al. TLR-2 and TLR-9 are sensors of apoptosis in a mouse model of doxorubicin-induced acute inflammation. Cell Death Differ 2011; 18: 1316-1325.

18. Tesniere A, Schlemmer F, Boige V, Kepp O, Martins I, Ghiringhelli F et al. Immunogenic death of colon cancer cells treated with oxaliplatin. Oncogene 2010; 29: 482-491.

19. Panaretakis T, Kepp O, Brockmeier U, Tesniere A, Bjorklund AC, Chapman DC et al. Mechanisms of pre-apoptotic calreticulin exposure in immunogenic cell death. EMBO $J$ 2009; 28: 578-590.

20. Merritt RE, Mahtabifard A, Yamada RE, Crystal RG, Korst RJ. Cisplatin augments cytotoxic T-lymphocyte-mediated antitumor immunity in poorly immunogenic murine lung cancer. J Thorac Cardiovasc Surg 2003; 126: 1609-1617.

21. Obeid M, Panaretakis T, Joza N, Tufi R, Tesniere A, van Endert $P$ et al. Calreticulin exposure is required for the immunogenicity of gamma-irradiation and UVC light-induced apoptosis. Cell Death Differ 2007; 14: 1848-1850.

22. Suzuki Y, Mimura K, Yoshimoto Y, Watanabe M, Ohkubo Y, Izawa S et al. Immunogenic tumor cell death induced by chemoradiotherapy in patients with esophageal squamous cell carcinoma. Cancer Res 2012; 72: 3967-3976.

23. Rubner Y, Wunderlich R, Ruhle PF, Kulzer L, Werthmoller N, Frey B et al. How does ionizing irradiation contribute to the induction of anti-tumor immunity? Front Oncol 2012; 2: 75 .

24. Matzinger P. The danger model: a renewed sense of self. Science 2002; 296: 301-305.

25. Matzinger P. Tolerance, danger, and the extended family. Annu Rev Immunol 1994; 12 : 991-1045.

26. Kroemer G, Galluzzi L, Kepp O, Zitvogel L. Immunogenic cell death in cancer therapy. Annu Rev Immunol 2012; 31: 51-72.

27. Krysko DV, Garg AD, Kaczmarek A, Krysko O, Agostinis P, Vandenabeele P. Immunogenic cell death and DAMPs in cancer therapy. Nat Rev Cancer 2012; 12 : 860-875.

28. Dudek AM, Garg AD, Krysko DV, De Ruysscher D, Agostinis P. Inducers of immunogenic cancer cell death. Cytokine Growth Factor Rev 2013.

29. Panaretakis T, Joza N, Modjtahedi N, Tesniere A, Vitale I, Durchschlag M et al. The co-translocation of ERp57 and calreticulin determines the immunogenicity of cell death. Cell Death Differ 2008; 15: 1499-1509.

30. Apetoh L, Ghiringhelli F, Tesniere A, Obeid M, Ortiz C, Criollo A et al. Toll-like receptor 4-dependent contribution of the immune system to anticancer chemotherapy and radiotherapy. Nat Med 2007; 13: 1050-1059.

31. Ghiringhelli F, Apetoh L, Tesniere A, Aymeric L, Ma Y, Ortiz C et al. Activation of the NLRP3 inflammasome in dendritic cells induces IL-1beta-dependent adaptive immunity against tumors. Nat Med 2009; 15: 1170-1178. 
32. Schiavoni G, Sistigu A, Valentini M, Mattei F, Sestili $P$, Spadaro $F$ et al. Cyclophosphamide synergizes with type I interferons through systemic dendritic cell reactivation and induction of immunogenic tumor apoptosis. Cancer Res 2011; 71: 768-778.

33. Chen J, Xie J, Jiang Z, Wang B, Wang Y, Hu X. Shikonin and its analogs inhibit cancer cell glycolysis by targeting tumor pyruvate kinase-M2. Oncogene 2011; 30: 4297-4306.

34. Yang H, Zhou P, Huang H, Chen D, Ma N, Cui QC et al. Shikonin exerts antitumor activity via proteasome inhibition and cell death induction in vitro and in vivo. Int J Cancer 2009; 124: 2450-2459.

35. Spisek R, Charalambous A, Mazumder A, Vesole DH, Jagannath S, Dhodapkar MV Bortezomib enhances dendritic cell (DC)-mediated induction of immunity to human myeloma via exposure of cell surface heat shock protein 90 on dying tumor cells: therapeutic implications. Blood 2007; 109: 4839-4845.

36. Garrido G, Rabasa A, Sanchez B, Lopez MV, Blanco R, Lopez A et al. Induction of immunogenic apoptosis by blockade of epidermal growth factor receptor activation with a specific antibody. J Immunol 2011; 187: 4954-4966.

37. Menger L, Vacchelli E, Adjemian S, Martins I, Ma Y, Shen S et al. Cardiac glycosides exert anticancer effects by inducing immunogenic cell death. Sci Transl Med 2012; 4: 143 ra199.

38. Sonnemann J, Gressmann S, Becker S, Wittig S, Schmudde M, Beck JF. The histone deacetylase inhibitor vorinostat induces calreticulin exposure in childhood brain tumour cells in vitro. Cancer Chemother Pharmacol 2010; 66: 611-616.

39. Han W, Li L, Qiu S, Lu Q, Pan Q, Gu Y et al. Shikonin circumvents cancer drug resistance by induction of a necroptotic death. Mol Cancer Ther 2007; 6: 1641-1649.

40. Galluzzi L, Kepp O, Kroemer G. Enlightening the impact of immunogenic cell death in photodynamic cancer therapy. EMBO J 2012; 31: 1055-1057.

41. Verfaillie T, Rubio N, Garg AD, Bultynck G, Rizzuto R, Decuypere JP et al. PERK is required at the ER-mitochondrial contact sites to convey apoptosis after ROS-based ER stress. Cell Death Differ 2012; 19: 1880-1891.

42. Scaffidi P, Misteli T, Bianchi ME. Release of chromatin protein HMGB1 by necrotic cells triggers inflammation. Nature 2002; 418: 191-195.

43. Karioti A, Bilia AR. Hypericins as potential leads for new therapeutics. Int J Mol Sci 2010; 11: $562-594$

44. Zhang L, Wang A. Virus-induced ER stress and the unfolded protein response. Front Plant Sci 2012; 3: 293

45. Schwarz KB. Oxidative stress during viral infection: a review. Free Radic Biol Med 1996; 21: $641-649$.

46. Garg AD, Krysko DV, Vandenabeele P, Agostinis P. Hypericin-based photodynamic therapy induces surface exposure of damage-associated molecular patterns like HSP70 and calreticulin. Cancer Immunol Immunother 2012; 61: 215-221.

47. Obeid M, Tesniere A, Panaretakis T, Tufi R, Joza N, van Endert P et al. Ecto-calreticulin in immunogenic chemotherapy. Immunol Rev 2007; 220: 22-34.

48. Martin SJ, Reutelingsperger CP, McGahon AJ, Rader JA, van Schie RC, LaFace DM et al. Early redistribution of plasma membrane phosphatidylserine is a general feature of apoptosis regardless of the initiating stimulus: inhibition by overexpression of $\mathrm{Bcl}-2$ and Abl. J Exp Med 1995; 182: 1545-1556.

49. Martins I, Kepp O, Schlemmer F, Adjemian S, Tailler M, Shen S et al. Restoration of the immunogenicity of cisplatin-induced cancer cell death by endoplasmic reticulum stress. Oncogene 2011; 30: 1147-1158.

50. Garg AD, Nowis D, Golab J, Vandenabeele P, Krysko DV, Agostinis P. Immunogenic cell death, DAMPs and anticancer therapeutics: an emerging amalgamation. Biochim Biophys Acta 2010; 1805: 53-71.

51. Kazama H, Ricci JE, Herndon JM, Hoppe G, Green DR, Ferguson TA. Induction of immunological tolerance by apoptotic cells requires caspase-dependent oxidation of high-mobility group box-1 protein. Immunity 2008; 29: 21-32.

52. Andersson U, Wang H, Palmblad K, Aveberger AC, Bloom O, Erlandsson-Harris $\mathrm{H}$ et al. High mobility group 1 protein (HMG-1) stimulates proinflammatory cytokine synthesis in human monocytes. J Exp Med 2000; 192: 565-570.

53. Tesniere A, Apetoh L, Ghiringhelli F, Joza N, Panaretakis T, Kepp $O$ et al. Immunogenic cancer cell death: a key-lock paradigm. Curr Opin Immunol 2008; 20: 504-511.

54. Chiba S, Baghdadi M, Akiba H, Yoshiyama H, Kinoshita I, Dosaka-Akita H et al. Tumor-infiltrating DCs suppress nucleic acid-mediated innate immune responses through interactions between the receptor TIM-3 and the alarmin HMGB1. Nat Immunol 2012; 13: 832-842.

55. Apetoh L, Ghiringhelli F, Tesniere A, Criollo A, Ortiz C, Lidereau R et al. The interaction between HMGB1 and TLR4 dictates the outcome of anticancer chemotherapy and radiotherapy. Immunol Rev 2007; 220: 47-59.

56. Yang H, Hreggvidsdottir HS, Palmblad K, Wang H, Ochani M, Li J et al. A critical cysteine is required for HMGB1 binding to Toll-like receptor 4 and activation of macrophage cytokine release. Proc Natl Acad Sci USA 2010; 107: 11942-11947.

57. Jube S, Rivera ZS, Bianchi ME, Powers A, Wang E, Pagano I et al. Cancer cell secretion of the DAMP protein HMGB1 supports progression in malignant mesothelioma. Cancer Res 2012; 72: 3290-3301.

58. Yang GL, Zhang LH, Bo JJ, Huo XJ, Chen HG, Cao M et al. Increased expression of HMGB1 is associated with poor prognosis in human bladder cancer. J Surg Oncol 2012; 106: $57-61$.
59. Hoppe G, Talcott KE, Bhattacharya SK, Crabb JW, Sears JE. Molecular basis for the redox control of nuclear transport of the structural chromatin protein Hmgb1. Exp Cell Res 2006; 312: 3526-3538.

60. Venereau E, Casalgrandi M, Schiraldi M, Antoine DJ, Cattaneo A, De Marchis F et al. Mutually exclusive redox forms of HMGB1 promote cell recruitment or proinflammatory cytokine release. J Exp Med 2012; 209: 1519-1528.

61. Yang $\mathrm{H}$, Lundback $\mathrm{P}$, Ottosson L, Erlandsson-Harris $\mathrm{H}$, Venereau E, Bianchi ME et al. Redox modification of cysteine residues regulates the cytokine activity of high mobility group box-1 (HMGB1). Mol Med 2012; 18: 250-259.

62. Chaiswing L, Oberley TD. Extracellular/microenvironmental redox state. Antioxid Redox Signal 2010; 13: 449-465.

63. Policastro LL, Ibanez IL, Notcovich C, Duran HA, Podhajcer OL. The tumor microenvironment: characterization, redox considerations, and novel approaches for reactive oxygen species-targeted gene therapy. Antioxid Redox Signal 2012.

64. Guo ZS, Naik A, O'Malley ME, Popovic P, Demarco R, Hu Y et al. The enhanced tumor selectivity of an oncolytic vaccinia lacking the host range and antiapoptosis genes SPI-1 and SPI-2. Cancer Res 2005; 65: 9991-9998.

65. Diaconu I, Cerullo V, Hirvinen ML, Escutenaire S, Ugolini M, Pesonen SK et al. Immune response is an important aspect of the antitumor effect produced by a CD40L-encoding oncolytic adenovirus. Cancer Res 2012; 72: 2327-2338.

66. Elliott MR, Chekeni FB, Trampont PC, Lazarowski ER, Kadl A, Walk SF et al. Nucleotides released by apoptotic cells act as a find-me signal to promote phagocytic clearance. Nature 2009; 461: 282-286.

67. Martins I, Tesniere A, Kepp O, Michaud M, Schlemmer F, Senovilla L et al. Chemotherapy induces ATP release from tumor cells. Cell Cycle 2009; 8: 3723-3728.

68. Michaud M, Martins I, Sukkurwala $A Q$, Adjemian S, Ma Y, Pellegatti P et al. Autophagy-dependent anticancer immune responses induced by chemotherapeutic agents in mice. Science 2011; 334: 1573-1577.

69. Ohshima $Y$, Tsukimoto M, Takenouchi T, Harada H, Suzuki A, Sato M et al. Gamma-irradiation induces $\mathrm{P} 2 \mathrm{X}(7)$ receptor-dependent ATP release from B16 melanoma cells. Biochim Biophys Acta 2010; 1800: 40-46.

70. Petrovski G, Ayna G, Majai G, Hodrea J, Benko S, Madi A et al. Phagocytosis of cells dying through autophagy induces inflammasome activation and IL-1beta release in human macrophages. Autophagy 2011; 7: 321-330.

71. Chang CW, Li HC, Hsu CF, Chang CY, Lo SY. Increased ATP generation in the host cell is required for efficient vaccinia virus production. J Biomed Sci 2009; 16: 80.

72. Seror C, Melki MT, Subra F, Raza SQ, Bras M, Saidi H et al. Extracellular ATP acts on P2Y2 purinergic receptors to facilitate HIV-1 infection. J Exp Med 2011; 208: 1823-1834.

73. Maiuri MC, Zalckvar E, Kimchi A, Kroemer G. Self-eating and self-killing: crosstalk between autophagy and apoptosis. Nat Rev Mol Cell Biol 2007; 8: 741-752.

74. Amaravadi RK, Thompson CB. The roles of therapy-induced autophagy and necrosis in cancer treatment. Clin Cancer Res 2007; 13: 7271-7279.

75. Klionsky DJ, Emr SD. Autophagy as a regulated pathway of cellular degradation. Science 2000; 290: 1717-1721.

76. Eisenberg-Lerner A, Bialik S, Simon HU, Kimchi A. Life and death partners: apoptosis, autophagy and the cross-talk between them. Cell Death Differ 2009; 16: 966-975.

77. Kroemer G, Levine B. Autophagic cell death: the story of a misnomer. Nat Rev Mol Cell Biol 2008; 9: 1004-1010.

78. Qu X, Zou Z, Sun Q, Luby-Phelps K, Cheng P, Hogan RN et al. Autophagy gene-dependent clearance of apoptotic cells during embryonic development. Cell 2007; 128: $931-946$.

79. Martins I, Michaud M, Sukkurwala AQ, Adjemian S, Ma Y, Shen S et al. Premortem autophagy determines the immunogenicity of chemotherapy-induced cancer cell death. Autophagy 2012; 8: 413-415.

80. Townsend KN, Hughson LR, Schlie K, Poon VI, Westerback A, Lum JJ. Autophagy inhibition in cancer therapy: metabolic considerations for antitumor immunity. Immunol Rev 2012; 249: 176-194.

81. Amaravadi RK, Yu D, Lum JJ, Bui T, Christophorou MA, Evan Gl et al. Autophagy inhibition enhances therapy-induced apoptosis in a Myc-induced model of lymphoma. J Clin Invest 2007; 117: 326-336.

82. Yang ZJ, Chee CE, Huang S, Sinicrope FA. The role of autophagy in cancer: therapeutic implications. Mol Cancer Ther 2011; 10: 1533-1541.

83. Proskuryakov SY, Konoplyannikov AG, Gabai VL. Necrosis: a specific form of programmed cell death? Exp Cell Res 2003; 283: 1-16.

84. Kerr JF, Wyllie AH, Currie AR. Apoptosis: a basic biological phenomenon with wide-ranging implications in tissue kinetics. Br J Cancer 1972; 26: 239-257.

85. Vandenabeele P, Declercq W, Van Herreweghe F, Vanden Berghe T. The role of the kinases RIP1 and RIP3 in TNF-induced necrosis. Sci Signal 2010; 3: re4.

86. Wyllie AH, Kerr JF, Currie AR. Cell death: the significance of apoptosis. Int Rev Cytol 1980; 68: 251-306.

87. Van Herreweghe F, Festjens N, Declercq W, Vandenabeele P. Tumor necrosis factor-mediated cell death: to break or to burst, that's the question. Cell Mol Life Sci 2010; 67: $1567-1579$

88. Festjens N, Vanden Berghe T, Vandenabeele P. Necrosis, a well-orchestrated form of cell demise: signalling cascades, important mediators and concomitant immune response. Biochim Biophys Acta 2006; 1757: 1371-1387. 
89. Golstein P, Kroemer G. Cell death by necrosis: towards a molecular definition Trends Biochem Sci 2007; 32: 37-43.

90. Zhang DW, Shao J, Lin J, Zhang N, Lu BJ, Lin SC et al. RIP3, an energy metabolism regulator that switches TNF-induced cell death from apoptosis to necrosis. Science 2009 325: 332-336.

91. Holler N, Zaru R, Micheau O, Thome M, Attinger A, Valitutti S et al. Fas triggers an alternative, caspase-8-independent cell death pathway using the kinase RIP as effector molecule. Nat Immunol 2000; 1: 489-495.

92. Kamata H, Honda S, Maeda S, Chang L, Hirata H, Karin M. Reactive oxygen species promote TNFalpha-induced death and sustained JNK activation by inhibiting MAP kinase phosphatases. Cell 2005; 120: 649-661.

93. Zong WX, Ditsworth D, Bauer DE, Wang ZQ, Thompson CB. Alkylating DNA damage stimulates a regulated form of necrotic cell death. Genes Dev 2004; 18: 1272-1282.

94. Skulachev VP. Bioenergetic aspects of apoptosis, necrosis and mitoptosis. Apoptosis 2006; 11: 473-485

95. Todaro M, Alea MP, Di Stefano AB, Cammareri P, Vermeulen L, lovino F et al. Colon cancer stem cells dictate tumor growth and resist cell death by production of interleukin-4. Cell Stem Cell 2007; 1: 389-402.

96. Madjd Z, Mehrjerdi AZ, Sharifi AM, Molanaei S, Shahzadi SZ, Asadi-Lari M. CD44 ${ }^{+}$ cancer cells express higher levels of the anti-apoptotic protein Bcl-2 in breast tumours. Cancer Immun 2009; 9: 4

97. Bergsbaken T, Fink SL, Cookson BT. Pyroptosis: host cell death and inflammation. Nat Rev Microbiol 2009; 7: 99-109.

98. Frantz S, Ducharme A, Sawyer D, Rohde LE, Kobzik L, Fukazawa R et al. Targeted deletion of caspase-1 reduces early mortality and left ventricular dilatation following myocardial infarction. J Mol Cell Cardiol 2003; 35: 685-694.

99. Colunga AG, Laing JM, Aurelian L. The HSV-2 mutant DeltaPK induces melanoma oncolysis through nonredundant death programs and associated with autophagy and pyroptosis proteins. Gene Ther 2010; 17: 315-327.

100. Wang Q, Imamura R, Motani K, Kushiyama H, Nagata S, Suda T. Pyroptotic cells externalize eat-me and release find-me signals and are efficiently engulfed by macrophages. Int Immunol 2013; 25: 363-372.

101. Bridle BW, Stephenson KB, Boudreau JE, Koshy S, Kazdhan N, Pullenayegum E et al. Potentiating cancer immunotherapy using an oncolytic virus. Mol Ther 2010; 18 : 1430-1439.

102. Galluzzi L, Brenner C, Morselli E, Touat Z, Kroemer G. Viral control of mitochondrial apoptosis. PLoS Pathogen 2008; 4: e1000018.

103. Levine B, Mizushima N, Virgin HW. Autophagy in immunity and inflammation. Nature 2011; 469: 323-335.

104. Meng $\mathrm{X}$, Nakamura $\mathrm{T}$, Okazaki $\mathrm{T}$, Inoue $\mathrm{H}$, Takahashi $\mathrm{A}$, Miyamoto $\mathrm{S}$ et al. Enhanced antitumor effects of an engineered measles virus Edmonston strain expressing the wild-type N, P, L genes on human renal cell carcinoma. Mol Ther 2010; 18: $544-551$.

105. Hasei J, Sasaki T, Tazawa H, Osaki S, Yamakawa Y, Kunisada T et al. Dual programmed cell death pathways induced by p53 transactivation overcome resistance to oncolytic adenovirus in human osteosarcoma cells. Mol Cancer Ther 2013; 12: 314-325.

106. Moussavi M, Fazli L, Tearle H, Guo Y, Cox M, Bell J et al. Oncolysis of prostate cancers induced by vesicular stomatitis virus in PTEN knockout mice. Cancer Res 2010; 70 . 1367-1376.

107. Kirn D, Martuza RL, Zwiebel J. Replication-selective virotherapy for cancer: biological principles, risk management and future directions. Nat Med 2001; 7: 781-787.

108. Prestwich RJ, Harrington KJ, Pandha HS, Vile RG, Melcher AA, Errington F Oncolytic viruses: a novel form of immunotherapy. Expert Rev Anticancer Ther 2008 8: $1581-1588$.

109. Kepp O, Senovilla L, Galluzzi L, Panaretakis T, Tesniere A, Schlemmer F et al. Viral subversion of immunogenic cell death. Cell Cycle 2009; 8: 860-869.

110. Zhang Y, Chirmule N, Gao GP, Qian R, Croyle M, Joshi B et al. Acute cytokine response to systemic adenoviral vectors in mice is mediated by dendritic cells and macrophages. Mol Ther 2001; 3(Part 1): 697-707.

111. Benencia F, Courreges MC, Conejo-Garcia JR, Mohamed-Hadley A, Zhang L, Buckanovich RJ et al. HSV oncolytic therapy upregulates interferon-inducible chemokines and recruits immune effector cells in ovarian cancer. Mol Ther 2005; 12 789-802.

112. Vicari AP, Chiodoni C, Vaure C, Ait-Yahia S, Dercamp C, Matsos F et al. Reversal of tumor-induced dendritic cell paralysis by $\mathrm{CpG}$ immunostimulatory oligonucleotide and anti-interleukin 10 receptor antibody. J Exp Med 2002; 196: 541-549.

113. Errington F, Steele L, Prestwich R, Harrington KJ, Pandha HS, Vidal L et al. Reovirus activates human dendritic cells to promote innate antitumor immunity. J Immunol 2008 180: 6018-6026.

114. Donnelly OG, Errington-Mais F, Steele L, Hadac E, Jennings V, Scott K et al. Measles virus causes immunogenic cell death in human melanoma. Gene Ther 2013; 20 $7-15$
115. Huang B, Sikorski R, Kirn DH, Thorne SH. Synergistic anti-tumor effects between oncolytic vaccinia virus and paclitaxel are mediated by the IFN response and HMGB1. Gene Ther 2011; 18: 164-172.

116. Borde C, Barnay-Verdier S, Gaillard C, Hocini H, Marechal V, Gozlan J. Stepwise release of biologically active HMGB1 during HSV-2 infection. PLOS One 2011; 6: e16145.

117. Moisy D, Avilov SV, Jacob Y, Laoide BM, Ge X, Baudin F et al. HMGB1 protein binds to influenza virus nucleoprotein and promotes viral replication. J Virol 2012; 86: 9122-9133.

118. Zhang HM, Ye X, Su Y, Yuan J, Liu Z, Stein DA et al. Coxsackievirus B3 infection activates the unfolded protein response and induces apoptosis through downregulation of p58IPK and activation of CHOP and SREBP1. J Virol 2010; 84: 8446-8459.

119. Chau DH, Yuan J, Zhang H, Cheung P, Lim T, Liu Z et al. Coxsackievirus B3 proteases $2 \mathrm{~A}$ and $3 \mathrm{C}$ induce apoptotic cell death through mitochondrial injury and cleavage of elF4GI but not DAP5/p97/NAT1. Apoptosis 2007; 12: 513-524.

120. Ito $\mathrm{H}$, Aoki H, Kuhnel F, Kondo Y, Kubicka S, Wirth T et al. Autophagic cell death of malignant glioma cells induced by a conditionally replicating adenovirus. J Natl Cancer Inst 2006; 98: 625-636.

121. Jiang $\mathrm{H}$, Gomez-Manzano $\mathrm{C}$, Aoki $\mathrm{H}$, Alonso MM, Kondo S, McCormick $\mathrm{F}$ et al. Examination of the therapeutic potential of Delta-24-RGD in brain tumor stem cells: role of autophagic cell death. J Natl Cancer Inst 2007; 99: 1410-1414.

122. Tazawa $H$, Yano S, Yoshida R, Yamasaki $Y$, Sasaki $T$, Hashimoto $Y$ et al. Genetically engineered oncolytic adenovirus induces autophagic cell death through an E2F1-microRNA-7-epidermal growth factor receptor axis. Int J Cancer 2012; 131: 2939-2950.

123. Meng C, Zhou Z, Jiang K, Yu S, Jia L, Wu Y et al. Newcastle disease virus triggers autophagy in U251 glioma cells to enhance virus replication. Arch Virol 2012; 157: 1011-1018.

124. Thirukkumaran $\mathrm{CM}$, Shi ZQ, Luider J, Kopciuk $\mathrm{K}$, Gao $\mathrm{H}$, Bahlis $\mathrm{N}$ et al. Reovirus modulates autophagy during oncolysis of multiple myeloma. Autophagy 2013; 9: 413-414

125. Hu X, Xuan Y. Bypassing cancer drug resistance by activating multiple death pathways-a proposal from the study of circumventing cancer drug resistance by induction of necroptosis. Cancer Lett 2008; 259: 127-137.

126. Huang $\mathrm{H}$, Xiao $\mathrm{T}$, He L, Ji H, Liu XY. Interferon-beta-armed oncolytic adenovirus induces both apoptosis and necroptosis in cancer cells. Acta Biochim Biophys Sin (Shanghai) 2012; 44: 737-745.

127. Jablonska J, Leschner S, Westphal K, Lienenklaus S, Weiss S. Neutrophils responsive to endogenous IFN-beta regulate tumor angiogenesis and growth in a mouse tumor model. J Clin Invest 2010; 120: 1151-1164.

128. Tough DF, Borrow $P$, Sprent J. Induction of bystander T cell proliferation by viruses and type I interferon in vivo. Science 1996; 272: 1947-1950.

129. Qin XQ, Beckham C, Brown JL, Lukashev M, Barsoum J. Human and mouse IFN-beta gene therapy exhibits different anti-tumor mechanisms in mouse models. Mol Ther 2001; 4: $356-364$

130. Chiocca EA. The host response to cancer virotherapy. Curr Opin Mol Ther 2008; 10 : 38-45.

131. Melcher A, Parato K, Rooney CM, Bell JC. Thunder and lightning: immunotherapy and oncolytic viruses collide. Mol Ther 2011; 19: 1008-1016.

132. Kottke T, Diaz RM, Kaluza K, Pulido J, Galivo F, Wongthida P et al. Use of biological therapy to enhance both virotherapy and adoptive T-cell therapy for cancer. Mol Ther 2008; 16: 1910-1918.

133. Garg AD, Krysko DV, Vandenabeele P, Agostinis P. DAMPs and PDT-mediated photo-oxidative stress: exploring the unknown. Photochem Photobiol Sci 2011; 10: 670-680.

134. Garg AD, Krysko DV, Vandenabeele P, Agostinis $P$. The emergence of phox-ER stress induced immunogenic apoptosis. Oncoimmunology 2012; 1: 786-788.

135. Shen F, Chu S, Bence AK, Bailey B, Xue X, Erickson PA et al. Quantitation of doxorubicin uptake, efflux, and modulation of multidrug resistance (MDR) in MDR human cancer cells. J Pharmacol Exp Ther 2008; 324: 95-102.

136. Fridman WH, Pages F, Sautes-Fridman C, Galon J. The immune contexture in human tumours: impact on clinical outcome. Nat Rev Cancer 2012; 12: 298-306.

137. Grivennikov SI, Greten FR, Karin M. Immunity, inflammation, and cancer. Cell 2010; 140 : 883-899.

138. Hanahan D, Weinberg RA. Hallmarks of cancer: the next generation. Cell 2011; 144 646-674

139. Kanai R, Wakimoto H, Martuza RL, Rabkin SD. A novel oncolytic herpes simplex virus that synergizes with phosphoinositide 3-kinase/Akt pathway inhibitors to target glioblastoma stem cells. Clin Cancer Res 2011; 17: 3686-3696.

140. Cripe TP, Wang PY, Marcato $P$, Mahller YY, Lee PW. Targeting cancer-initiating cells with oncolytic viruses. Mol Ther 2009; 17: 1677-1682. 